\title{
Trifluoromethyl-substituted tetrathiafulvalenes
}

\author{
Olivier Jeannin, Frédéric Barrière and Marc Fourmigué*
}

\author{
Full Research Paper \\ Address: \\ Institut des Sciences Chimiques de Rennes, UMR 6226 \\ CNRS-Université de Rennes I, Campus de Beaulieu, 35042 Rennes, \\ France \\ Email: \\ Marc Fourmigué* - marc.fourmigue@univ-rennes1.fr \\ * Corresponding author \\ Keywords: \\ electrochemistry; electron withdrawing group (EWG); fluorine; \\ tetrathiafulvalene (TTF)
}

Open Access

Beilstein J. Org. Chem. 2015, 11, 647-658.

doi:10.3762/bjoc. 11.73

Received: 16 February 2015

Accepted: 15 April 2015

Published: 06 May 2015

This article is part of the Thematic Series "Tetrathiafulvalene chemistry".

Guest Editor: P. J. Skabara

(C) 2015 Jeannin et al; licensee Beilstein-Institut. License and terms: see end of document.

\begin{abstract}
A series of tetrathiafulvalenes functionalized with one or two trifluoromethyl electron-withdrawing groups (EWG) is obtained by phosphite coupling involving $\mathrm{CF}_{3}$-substituted 1,3-dithiole-2-one derivatives. The relative effects of the $\mathrm{EWG}_{\mathrm{such}}$ as $\mathrm{CF}_{3}, \mathrm{CO}_{2} \mathrm{Me}$ and $\mathrm{CN}$ on the TTF core were investigated from a combination of structural, electrochemical, spectrochemical and theoretical investigations. Electrochemical data confirm the good correlations between the first oxidation potential of the TTF derivatives and the $\sigma_{\text {meta }}$ Hammet parameter, thus in the order $\mathrm{CO}_{2} \mathrm{Me}<\mathrm{CF}_{3}<\mathrm{CN}$, indicating that, in any case, the mesomeric effect of the substituents is limited. Besides, crystal structure determinations show that the deformation of the unsymmetrically substituted dithiole rings, when bearing one, or two different EWG, and attributed to the mesomeric effect of ester or nitrile groups, is not notably modified or counter-balanced by the introduction of a neighboring trifluoromethyl group. DFT calculations confirm these observations and also show that the low energy HOMO-LUMO absorption band found in nitrile or ester-substituted TTFs is not found in TTF- $\mathrm{CF}_{3}$, where, as in TTF itself, the low energy absorption band is essentially attributable to a HOMO $\rightarrow$ LUMO +1 transition. Despite relatively high oxidation potentials, these donor molecules with $\mathrm{CF}_{3}$ EWG can be involved in charge transfer complexes or cation radical salts, as reported here for the $\mathrm{CF}_{3}$-subsituted EDT-TTF donor molecule. A neutral charge transfer complex with TCNQ, $(\text { EDT-TTF-CF })_{2}$ (TCNQ) was isolated and characterized through alternated stacks of EDT-TTF-CF 3 dimers and TCNQ in the solid state. A radical cation salt of EDT-TTF- $\mathrm{CF}_{3}$ is also obtained upon electrocrystallisation in the presence of the $\mathrm{FeCl}_{4}{ }^{-}$anion. In this salt, formulated as $\left(\mathrm{EDT}-\mathrm{TTF}-\mathrm{CF}_{3}\right)\left(\mathrm{FeCl}_{4}\right)$, the (EDT-TTF-CF $)^{+\bullet}$ radical cations are associated two-by-two into centrosymmetric dyads with a strong pairing of the radical species in a singlet state.
\end{abstract}

\section{Introduction}

Following three decades of extensive work toward the elaboration of conducting radical cation salts from tetrathiafulvalene (TTF) derivatives with electron-rich alkyl (tetramethyltetrathiafulvalene: TMTTF, tetramethyltetraselenafulvalene: TMTSF) or thioalkyl (ethylenedithiotetrathiafulvalene: EDT-TTF, bis(ethylenedithio)tetrathiafulvalene: BEDT-TTF) substituents [1], investigations of radical cation salts of tetrathiafulvalenes functionalized by electron-withdrawing groups (EWG) are less 
documented, essentially because the presence of such substituents as halogen, acyl, ester, amide or nitrile on the TTF redox core dramatically increases its oxidation potential and destabilizes the radical cation form. This strong anodic shift is particularly noticeable in tetrasubstituted TTFs such as $\operatorname{TTF}\left(\mathrm{CO}_{2} \mathrm{Me}\right)_{4}$ [2-4], $\mathrm{TTFCl}_{4}[5], \operatorname{TTF}\left(\mathrm{CF}_{3}\right)_{4}$ [2], or $\operatorname{TTF}(\mathrm{CN})_{4}$ [3], which oxidize into the radical cation at $0.80,0.83,1.05$ or $1.12 \mathrm{~V}$ vs SCE respectively, to be compared with TTF itself which oxidizes at $0.33 \mathrm{~V}$ vs SCE. The associated instability of these radical species in moist air hindered in most cases their isolation in cation radical salts. This is all the more unfortunate since the electronegative atoms $(\mathrm{O}, \mathrm{N}, \mathrm{Hal})$ within such $\mathrm{EWG}$ are expected to be able to engage, in the solid state at the organic-inorganic interface, in a variety of secondary nonbonding interactions such as hydrogen or halogen bonding $[6,7]$, an issue of current strong interest in organic solid state chemistry $[8,9]$. However, it was also recognized that the introduction of only one or two of such EWG on the TTF core could limit this anodic shift, and accordingly, several tetrathiafulvalenes bearing only one or two ester [10], nitrile [11-14], amide [7,15-17], thioamide [18-20], or halogen [5] substituents were successfully engaged in radical cation salts by electrocrystallization, with intermolecular hydrogen [21-23] of halogen bond interactions [24-27]. Within such TTF derivatives, as reported by Bryce [28], an internal charge transfer (ICT) between the TTF and the EWG moieties increases the hydrophilicity of the TTF head groups and facilitates monolayer formation on the water surface for the preparation of Langmuir-Blodgett films. The structural and electronic properties of a series of ester [15], thioester [29,30], tertiary amide and thioamide [12] TTF derivatives have been then rationalized, based on: (i) the sizeable contribution of the mesomeric form $\mathrm{B}$ (Scheme 1) and, (ii) an ICT from the TTF-based HOMO to the EWG-based LUMO, also observed in primary and secondary amides [10]. Another consequence of the contribution of the $\mathrm{B}$ form is the shortening of the $\mathrm{C}-\mathrm{S}$ bond opposite to the $\mathrm{EWG}$, experimentally observed in the structures of such molecules.

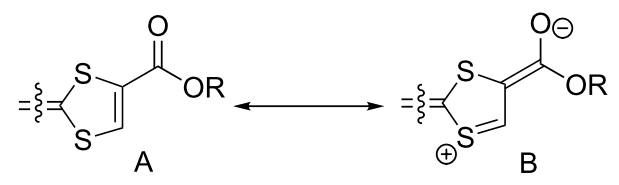

Scheme 1: Mesomeric forms of 1,3-dithiole rings substituted with EWG.

More recently, we have reported another series of TTFs functionalized at various positions with the electron-withdrawing $-\mathrm{CF}_{3}$ (trifluoromethyl) group such as EDT-TTF $\left(\mathrm{CF}_{3}\right)(\mathbf{1 c})$ or EDT-TTF $\left(\mathrm{CF}_{3}\right)_{2}$ (2cc) (Scheme 2) [31]. Single-crystal X-ray diffraction measurements revealed the recurrent formation of layered structures with a strong segregation of the fluorinated moieties and formation of fluorine bilayers [32,33], attributed to the amphiphilic character of those TTF derivatives upon $\mathrm{CF}_{3}$ functionalization. A strong anodic shift of the first oxidation potential was also noted for $1 \mathbf{c}$ and $2 \mathbf{c c}$, when compared with the unsubstituted EDT-TTF molecule.

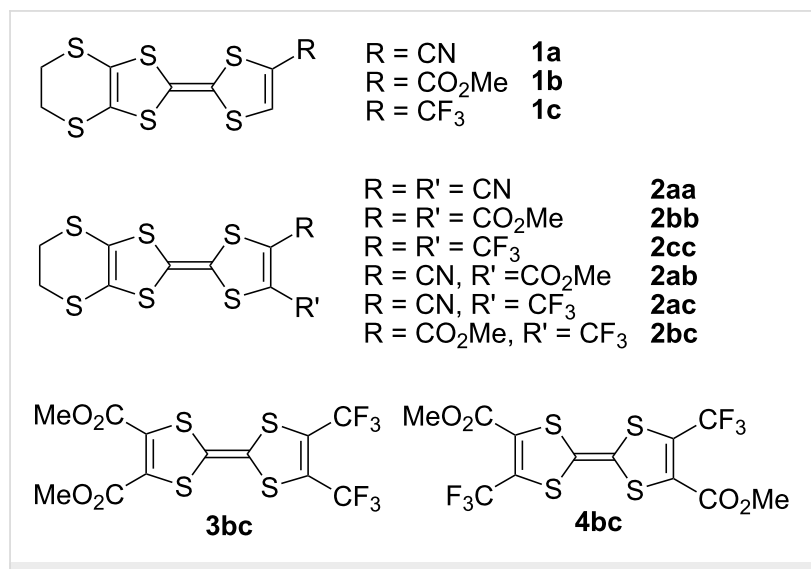

Scheme 2: Investigated TTF derivatives bearing EWG.

This work has been extended here to several novel disubstituted tetrathiafulvalenes bearing one $\mathrm{CF}_{3}$ group and one ester or nitrile group at the neighboring position as in $\mathbf{2 a c}$ and $\mathbf{2 b c}$ (Scheme 2). These derivatives offer an invaluable opportunity to evaluate the influence of the nature of the EWG on the structural and electronic properties of the TTF redox moiety, taking advantage of the marked differences between the three EWG now available: (i) the strongly electron withdrawing $-\mathrm{CN}$ group, (ii) the weaker $-\mathrm{CO}_{2} \mathrm{Me}$ group, both with important mesomeric effects, and, (iii) the $-\mathrm{CF}_{3}$ group, expected to exhibit essentially a strong $-\mathrm{I}$ inductive effect. Among the nine possible combinations $\mathbf{1}$ and $\mathbf{2}$ described above (Scheme 2), the unsymmetrically disubstituted $\mathbf{2 a b}$ and $\mathbf{2 a c}$ have not been reported to date. We describe here the syntheses of $\mathbf{2 a c}$ from $\mathbf{2 b c}$ and the single-crystal X-ray structure determinations of both $2 \mathbf{a c}$ and $\mathbf{2 b c}$ molecules. The preparation of the two positional isomers of bis(trifluoromethyl)-bis(carboxymethyl)tetrathiafulvalene $3 \mathbf{b c}$ and $\mathbf{4 b c}$ is also reported. The evolutions of (i) the geometry of the dithiole ring bearing the EWG, (ii) the electrochemical properties, (iii) the optical absorption (UV-vis) properties will be analyzed within the series, in order to evaluate the role of the $\mathrm{CF}_{3}$ group as electron-withdrawing substituent on the structural and electronic properties of the tetrathiafulvalene core, by comparison with that of the $-\mathrm{CO}_{2} \mathrm{Me}$ or $-\mathrm{CN}$ substituents. Furthermore, from the mono-substituted trifluoromethyl derivative 1c, we were also able to isolate a charge transfer complex with TCNQ and a cation radical salt with $\mathrm{FeCl}_{4}{ }^{-}$. The structures of both compounds will be de- 
scribed, and the geometrical evolutions of the TTF core upon oxidation analyzed by comparison with the structure of neutral $1 c$.

\section{Results and Discussion Syntheses}

The reported preparation of $\mathbf{2} \mathbf{b c}$ is based on the coupling reaction of the trithiocarbonate $\mathbf{5}$ with the dithiocarbonate $\mathbf{6 b c}$ affording also the symmetrical coupling product $\mathbf{4 b c}$ (Scheme 3) [31]. Further decarboxylation of $\mathbf{2 b c}$ with $\mathrm{LiBr} / \mathrm{DMF}$ afforded 1c while reaction with $\mathrm{NH}_{3}$ in $\mathrm{MeOH}$ gives the corresponding primary amide 7 in $63 \%$ yield. Its dehydration with $\mathrm{POCl}_{3}$ in sulfolane gives $\mathbf{2 a c}$ in $60 \%$ yield.

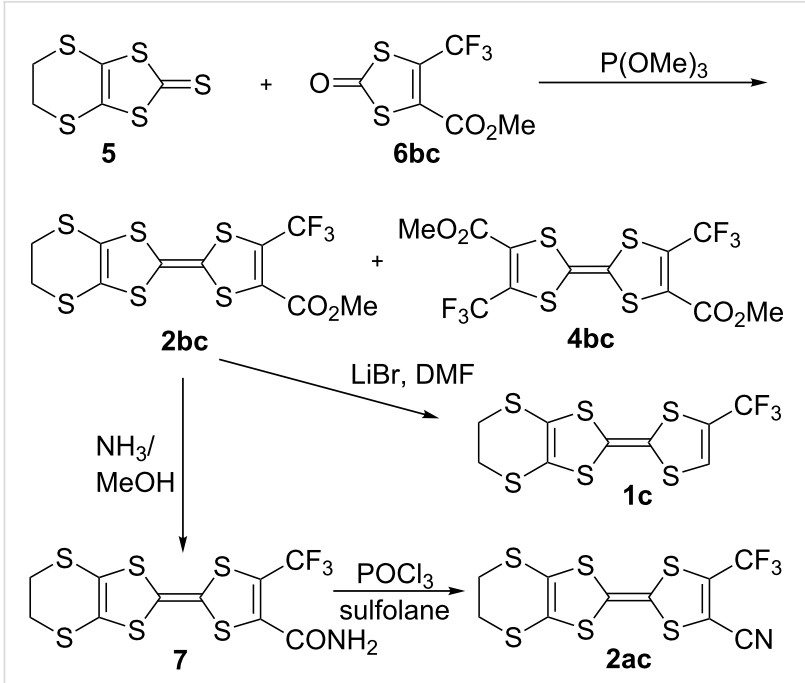

Scheme 3: Synthetic procedures to the $\mathrm{CF}_{3}$-substituted 4 bc, 1c and 2ac molecules.

A similar phosphite-based cross-coupling reaction between the bis(trifluoromethyl)-1,3-dithiole-2-one derivative 9cc and the diester derivative $\mathbf{1 0 b b}$ gave the TTF $\mathbf{3 b c}$ in $15 \%$ yield (Scheme 4).

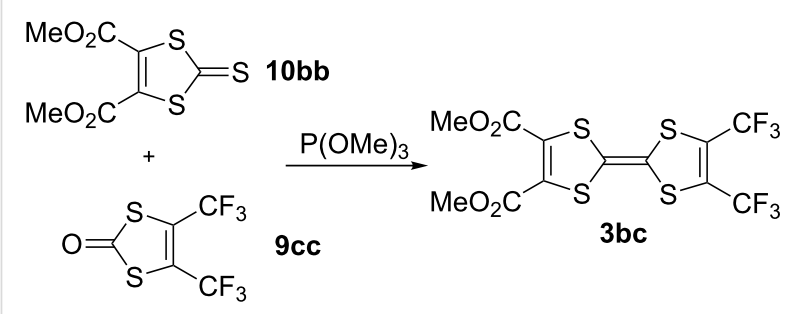

Scheme 4: Synthetic procedure to $3 \mathrm{bc}$.

With these extensive series at hand, it is now interesting to evaluate the role of the $\mathrm{CF}_{3}$ group as electron-withdrawing substituent on the structural and electronic properties of the tetrathiafulvalene core and to compare them with those of the $-\mathrm{CO}_{2} \mathrm{Me}$ or $-\mathrm{CN}$ substituents. This will be done here following two different approaches. First, we report the redox and optical absorption properties of the TTFs in solution, correlated with the electron-withdrawing character of the different substituents. Then, the relative effect of the three EWG on the solid state geometry of the dithiole ring will be described, based on the X-ray crystal structure analyses of four neutral TTF derivatives, i.e., the EDT-TTF derivatives $\mathbf{2 a c}$ and $\mathbf{2 b c}$ and the tetrasubstituted derivatives $\mathbf{3 b c}$ and $\mathbf{4 b c}$.

\section{Redox properties}

Cyclic voltammetry was used to evaluate the evolution of the donor strength with the nature and number of EWG. All derivatives exhibit two reversible oxidation waves. The $E_{1 / 2}$ values for the EDT-TTF derivatives with one or two EWG are collected in Table 1. Compared with the unsubstituted EDTTTF parent compound, redox potentials are shifted toward more anodic potentials with the introduction of the EWG with the following order $\mathrm{CO}_{2} \mathrm{Me}<\mathrm{CF}_{3} \leq \mathrm{CN}$. Note that this order is also confirmed by the evolution of the redox potentials of the tetrasubstituted TTF derivatives collected in Table 2.

Earlier electrochemical investigations of various tetrathiafulvalene derivatives have shown that the best correlations between the first oxidation potential and the Hammet parameters [39-41] were actually found with the $\sigma_{\text {meta }}$ constant of each substituent on the TTF core $[20,42]$, indicating that, in any case, the mesomeric effect of the substituents was small. A similar satisfactory correlation with all TTF derivatives described here is shown in Figure 1 and demonstrates that the trifluoromethyl

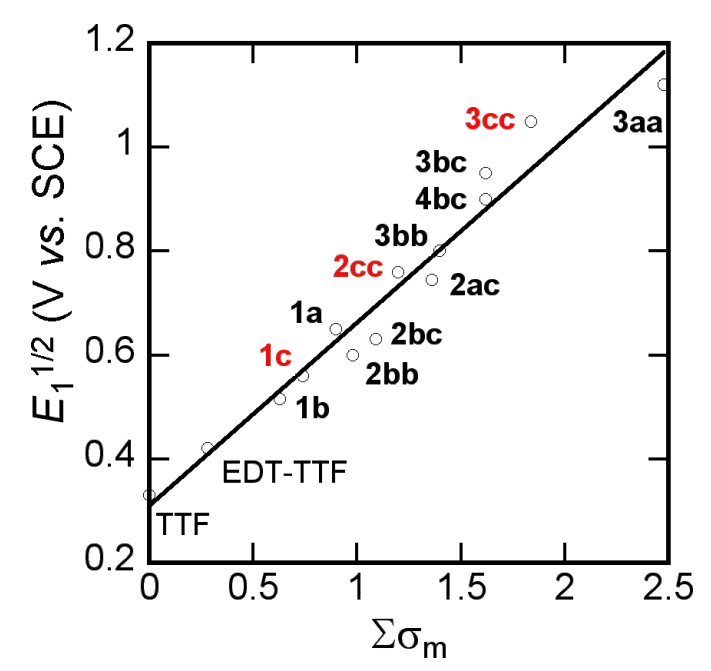

Figure 1: Correlation between the first oxidation potential $E_{1 / 2}$ and the sum of the Hammet $\sigma_{\text {meta }}$ parameters. TTF that only contain only $\mathrm{CF}_{3}$ EWG are given in red. 


\begin{tabular}{|c|c|c|c|c|c|c|c|c|}
\hline $\mathrm{RR}^{\prime}$ & solvent & $\begin{array}{l}\text { reference } \\
\text { electrode }\end{array}$ & $\begin{array}{l}E_{1 / 2(\mathrm{ox} 1)} \\
(\mathrm{V})\end{array}$ & $\begin{array}{l}E_{1 / 2(\mathrm{ox} 2)} \\
(\mathrm{V})\end{array}$ & $\begin{array}{l}\text { references } \\
\text { (electrochemistry) }\end{array}$ & $\Sigma \sigma_{\text {meta }}$ & $\lambda_{\max }(\varepsilon)$ & $\begin{array}{l}\text { references } \\
\text { (UV-vis) }\end{array}$ \\
\hline $\mathrm{H}, \mathrm{H}$ & $\mathrm{CH}_{3} \mathrm{CN}$ & SCE & 0.42 & 0.74 & {$[34,35]$} & 0.28 & $\begin{array}{l}441(451) \\
374(1266, \mathrm{sh})\end{array}$ & this work \\
\hline $\mathrm{H}, \mathrm{CO}_{2} \mathrm{Me}(\mathbf{1 b})$ & $\mathrm{CH}_{3} \mathrm{CN}$ & $\begin{array}{l}\mathrm{SCE} \\
\mathrm{Ag} / \mathrm{AgCl}\end{array}$ & $\begin{array}{l}0.515 \\
0.56\end{array}$ & $\begin{array}{l}0.825 \\
0.87\end{array}$ & [36] & 0.63 & $\begin{array}{l}480 \\
418\end{array}$ & [37] \\
\hline $\mathrm{H}, \mathrm{CF}_{3}(\mathbf{1 c})$ & $\mathrm{CH}_{2} \mathrm{Cl}_{2}$ & $\begin{array}{l}\mathrm{SCE} \\
\mathrm{FC}^{+} / \mathrm{FC}\end{array}$ & $\begin{array}{l}0.56 \\
0.17\end{array}$ & $\begin{array}{l}0.99 \\
0.60\end{array}$ & [17] & 0.74 & $374(2200)$ & this work \\
\hline $\mathrm{H}, \mathrm{CN}(\mathbf{1 a})$ & $\mathrm{PhCN}$ & SCE & 0.65 & 1.0 & [9] & 0.90 & $422(725)$ & this work \\
\hline $\mathrm{CO}_{2} \mathrm{Me}, \mathrm{CO}_{2} \mathrm{Me}(\mathbf{2 b b})$ & $\mathrm{CH}_{3} \mathrm{CN}$ & $\begin{array}{l}\mathrm{SCE} \\
\mathrm{Ag} / \mathrm{AgCl}\end{array}$ & $\begin{array}{l}0.595 \\
0.64\end{array}$ & $\begin{array}{l}0.905 \\
0.95\end{array}$ & [20] & 0.98 & $443(1310)$ & this work \\
\hline $\mathrm{CF}_{3}, \mathrm{CO}_{2} \mathrm{Me}(\mathbf{2 b c})$ & $\mathrm{CH}_{2} \mathrm{Cl}_{2}$ & $\begin{array}{l}\mathrm{SCE} \\
\mathrm{Fc}^{+} / \mathrm{FC}\end{array}$ & $\begin{array}{l}0.63 \\
0.24\end{array}$ & $\begin{array}{l}0.94 \\
0.64\end{array}$ & [17] & 1.09 & $467(10800)$ & this work \\
\hline $\mathrm{CF}_{3}, \mathrm{CF}_{3}(2 \mathrm{cc})$ & $\mathrm{CH}_{2} \mathrm{Cl}_{2}$ & $\begin{array}{l}\mathrm{SCE} \\
\mathrm{FC}^{+} / \mathrm{FC}\end{array}$ & $\begin{array}{l}0.76 \\
0.37\end{array}$ & $\begin{array}{l}1.15 \\
0.76\end{array}$ & [17] & 1.2 & $422(990)$ & this work \\
\hline $\mathrm{CN}, \mathrm{CF}_{3}(2 \mathrm{ac})$ & $\mathrm{CH}_{2} \mathrm{Cl}_{2}$ & $\begin{array}{l}\mathrm{SCE} \\
\mathrm{Fc}^{+} / \mathrm{FC}\end{array}$ & $\begin{array}{l}0.745 \\
0.355\end{array}$ & $\begin{array}{l}1.143 \\
0.753\end{array}$ & this work & 1.36 & $464(760)$ & this work \\
\hline $\mathrm{CN}, \mathrm{CN}(2 \mathrm{aa})$ & & & - & - & - & 1.52 & $500(464)$ & {$[11]$} \\
\hline
\end{tabular}

\begin{tabular}{|c|c|c|c|c|c|c|c|}
\hline & solvent & $E_{1 / 2(o \times 1)}$ & $E_{1 / 2(\mathrm{ox} 2)}$ & $\begin{array}{l}\text { references } \\
\text { (electrochemistry) }\end{array}$ & $\Sigma \sigma_{\text {meta }}$ & $\lambda_{\max }(\varepsilon)$ & $\begin{array}{l}\text { references } \\
\text { (UV-vis) }\end{array}$ \\
\hline TTF & $\mathrm{CH}_{3} \mathrm{CN}$ & 0.33 & 0.71 & {$[22]$} & 0 & $446(263)^{a}$ & {$[38]$} \\
\hline $\operatorname{TTF}\left(\mathrm{CO}_{2} \mathrm{Me}\right)_{4}(\mathbf{3 b b})$ & $\mathrm{CH}_{3} \mathrm{CN}$ & 0.83 & 1.10 & {$[22]$} & 1.4 & $445(1930)$ & {$[2,3]$} \\
\hline$o-\operatorname{TTF}\left(\mathrm{CO}_{2} \mathrm{Me}\right)_{2}\left(\mathrm{CF}_{3}\right)_{2}(3 \mathrm{bc})$ & $\mathrm{CH}_{2} \mathrm{Cl}_{2}$ & 0.95 & 1.28 & this work & 1.62 & $437(2430)$ & this work \\
\hline$E-\operatorname{TTF}\left(\mathrm{CO}_{2} \mathrm{Me}\right)_{2}\left(\mathrm{CF}_{3}\right)_{2}(\mathbf{4 b c})$ & $\mathrm{CH}_{2} \mathrm{Cl}_{2}$ & 0.90 & 1.23 & this work & 1.62 & $467(2280)$ & this work \\
\hline $\operatorname{TFF}\left(\mathrm{CF}_{3}\right)_{4}(3 \mathrm{cc})$ & $\mathrm{CH}_{3} \mathrm{CN}$ & 1.05 & 1.28 & {$[2]$} & 1.84 & $416(1390)$ & this work \\
\hline $\operatorname{TTF}(\mathrm{CN})_{4}(3 a a)$ & $\mathrm{CH}_{3} \mathrm{CN}$ & 1.12 & 1.22 & [3] & 2.48 & $502(2000)$ & [3] \\
\hline
\end{tabular}

aln $\mathrm{CH}_{3} \mathrm{CN}$.

group anodic shift observed in the order $\mathrm{CO}_{2} \mathrm{Me}<\mathrm{CF}_{3}<\mathrm{CN}$ correlate well with the $\sigma_{\text {meta }}$ Hammet constant.

\section{Optical properties}

The evolution of the lowest energy absorption bands is also reported for the different TTF derivatives in Table 1 and Table 2. We note that the introduction of the trifluoromethyl group induces a blue shift of these absorptions, by comparison with EWG such as $\mathrm{CO}_{2} \mathrm{Me}$ or $\mathrm{CN}$ which move the absorption bands toward lower energies This point is actually correlated to the observed color difference, as the trifluoromethyl-substituted TFF derivatives are lightly orange colored, while the ester and cyano TTFs are dark red compounds. In order to rationalize these evolutions, we have performed TD-DFT calculations on the model molecules TTF, TTF- $\mathrm{CF}_{3}$, TTF- $\mathrm{CO}_{2} \mathrm{Me}$ and TTF-
CN. The results are shown in Figure 2 and collected in Table 3, where a good correlation is found with the observed absorption bands experimentally observed in the four EDT-TTF derivatives, namely EDT-TTF, EDT-TTF- $\mathrm{CF}_{3}$ (1c), EDT$\mathrm{TTF}-\mathrm{CO}_{2} \mathrm{Me}(\mathbf{1 b})$ and EDT-TTF-CN (1a).

Several points need to be emphasized. In pristine TTF as in $\mathrm{TTF}-\mathrm{CF}_{3}$, the strongest, low energy transition is not the $\mathrm{HOMO} \rightarrow$ LUMO transition but the HOMO $\rightarrow$ LUMO +1 transition. Indeed, the LUMO in both molecules has a $\sigma$ character while the LUMO +1 has a $\pi$ character. By contrast, the ester and cyano groups (-M EWG) are strongly conjugated with the $\pi$ system to such a point that the order of the two lowest unoccupied orbitals is inverted. This inversion, with now a LUMO of $\pi$ character, allows for a direct $\mathrm{HOMO} \rightarrow$ LUMO optical tran- 


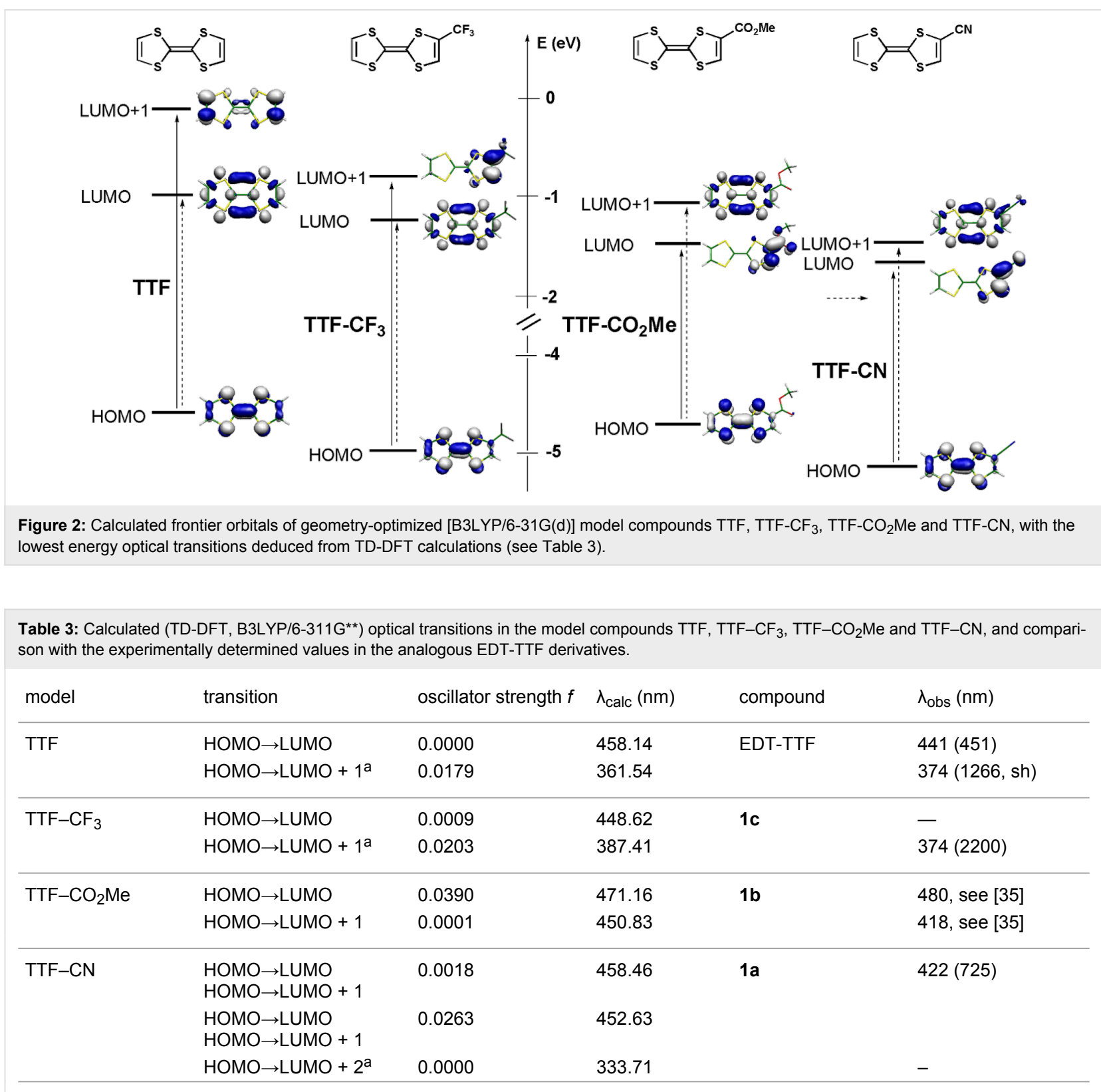

aThe HOMO $\rightarrow$ LUMO +4 is also involved in this transition. Cf Supporting Information File 1 for complete TD-DFT calculations.

sition in the two latter compounds. Besides, the $-\mathrm{I}$ inductive effect of the trifluoromethyl group stalilizes HOMO, LUMO and LUMO +1 of TTF. As a consequence, its lower energy absorptions are only slightly shifted by comparison with TTF, as experimentally observed. On the other hand, the strong stabilization of the LUMO in the ester- or cyano-substituted TTFs leads to a large red shift of the low energy absorption of these molecules. Note also that the relative energy of the HOMO of the four different model TTFs is well correlated with the ranking deduced from the electrochemical measurements. The stabilization of the HOMO, associated with the anodic shift of the first oxidation potential is indeed strongest with the cyano group, with the following ordering $\mathrm{H}<\mathrm{CO}_{2} \mathrm{Me}<\mathrm{CF}_{3}<\mathrm{CN}$, as discussed above (Table 1 and Table 2).

\section{X-ray crystal structures of the neutral donor molecules}

As mentioned in the Introduction, the substitution of one hydrogen atom on the TTF core by one EWG such as ester or cyano group is known to distort the dithiole ring, as illustrated in Scheme 1. In the following, we want to evaluate the extent of this effect in the case of the trifluoromethyl group, and its evolution in competitive situations where two different EWG are on the same dithiole ring. For that purpose, we could obtain 
good quality crystals of the trifluoromethyl-substituted EDTTTF derivatives with either one ester (in $2 \mathbf{a c}$ ) or one cyano group (in $\mathbf{2 b c}$ ) in ortho position to the $\mathrm{CF}_{3}$ group. 2 ac crystallizes in the monoclinic system, space group $P 2_{1}$, with one molecule in general position in the unit cell (Figure 3), affected by disorder on the ethylene bridge. On the other hand, 2bc crystallizes in the triclinic system, space group $P-1$, with one molecule in general position in the unit cell (Figure 4). The ester group is coplanar with the TTF core and adopts a s-trans conformation. In both compounds, the $\mathrm{CF}_{3}$ group is not disordered

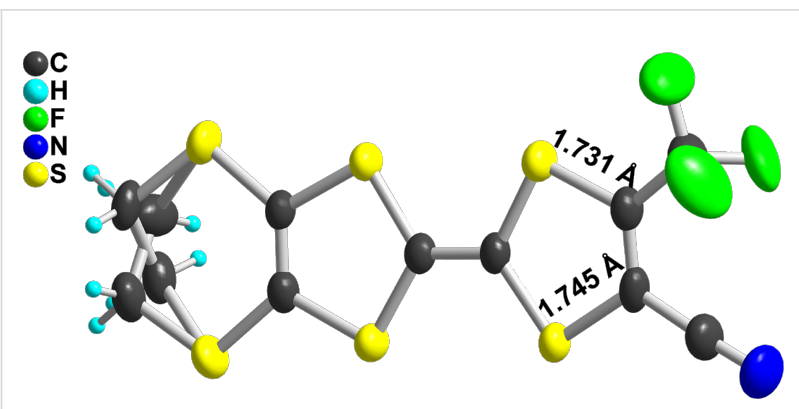

Figure 3: View of the 2ac molecule. Thermal ellipsoids are shown at the $50 \%$ probability level.

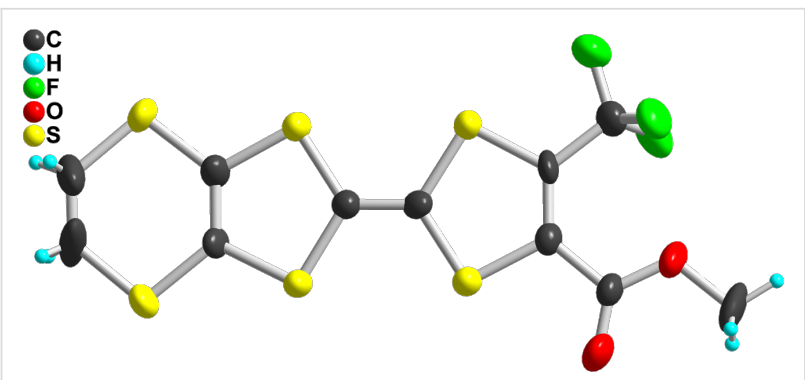

Figure 4: View of the $\mathbf{2 b c}$ molecule. Thermal ellipsoids are shown at the $50 \%$ probability level. as usually observed but adopts a fixed conformation with one fluorine atoms in the TTF mean plane, away from the other substituent. Bond lengths and angles are in the expected range. A dissymmetry of the $\mathrm{C}-\mathrm{S}$ bonds $\left(b, b^{\prime}\right.$ in Table 4$)$ in the dithiole ring bearing the different EWG is observed, with in both cases a shortening of the $\mathrm{C}-\mathrm{S}$ bond close to the $\mathrm{CF}_{3}$ group. This polarization of the dithiole ring bearing one such EWG has been rationalized by Bryce on the basis of a sizeable contribution of a zwitterionic mesomeric form due to the influence of the EWG of $-\mathrm{M}$ character (Scheme 1) $[8,17,18]$. The fact that in both 2 ac and 2 bc molecules, this shortening affects the $\mathrm{C}-\mathrm{S}$ bond closest to the $\mathrm{CF}_{3}$ group demonstrates unambiguously that the mesomeric electron-withdrawing effect of the $\mathrm{CN}$ or $\mathrm{CO}_{2} \mathrm{Me}$ groups is indeed stronger than that of $\mathrm{CF}_{3}$.

A similar effect is also observed on the structure of the symmetrical TTF 4 bc, which was obtained as symmetrical coupling product of $6 \mathbf{b c}$ during the preparation of $\mathbf{2 b c}$ (Scheme 2). $4 \mathbf{b c}$ crystallizes in the orthorhombic system, space group Pbam, with two crystallographically independent molecules, each of them located on a mirror plane and on an inversion center (Figure 5). In both molecules, a shorter $\mathrm{C}-\mathrm{S}$ bond length is observed opposite to the $\mathrm{CO}_{2} \mathrm{Me}$ groups (Table 3), demonstrating again here that the $(-\mathrm{M})$ mesomeric effect of the ester group exercises a stronger effect than the $(-\mathrm{I})$ inductive effect of the $\mathrm{CF}_{3}$ group.

Another interesting insight is provided by the X-ray crystal structure of the other isomer $\mathbf{3 b c}$, where each dithiole ring is substituted with the same substituents, two $\mathrm{CF}_{3}$ or two $\mathrm{CO}_{2} \mathrm{Me}$ groups (Figure 6). We note first that the $\mathrm{C}-\mathrm{S}$ bond distances (b) are now equal within the estimated standard deviations. We also observe that the localization of two $\mathrm{CF}_{3}$ moieties in ortho position to each other leads to a strong positional disorder of the fluorine atoms, at variance with the other structures described

Table 4: Evolution of bonds distances within the dithiole ring in EDT-TTF derivatives substituted with one or two EWG. Definition of the C-S $b$ and $b^{\prime}$ bond distances are given in the scheme below.

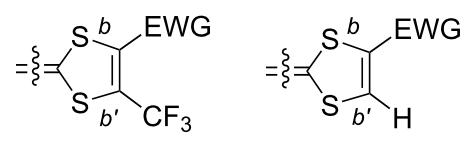

\begin{tabular}{lllll}
\hline compound & $b$ & $b^{\prime}$ & $100\left(b^{\prime}-b\right) / b^{\prime}$ & references \\
\hline $\mathrm{CN}, \mathrm{CF}_{3}(\mathbf{2 a c})$ & $1.745(5)$ & $1.731(9)$ & $-0.8 \%$ & this work \\
$\mathrm{CO}_{2} \mathrm{Me}, \mathrm{CF}_{3}(\mathbf{2 b c})$ & $1.727(23)$ & $1.715(33)$ & $-0.7 \%$ & this work \\
$\mathrm{E}-\mathrm{TTF}\left(\mathrm{CF}_{3}\right)_{2}\left(\mathrm{CO}_{2} \mathrm{Me}\right)_{2}(\mathbf{4 b c})$ & $1.744(4)$ & $1.734(4)$ & $-0.6 \%$ & this work \\
& $1.742(4)$ & $1.732(4)$ & $-0.6 \%$ & \\
\hline $\mathrm{H}, \mathrm{CN}(\mathbf{1 a})$ & $1.760(7)$ & $1.751(6)$ & $-0.5 \%$ & {$[9]$} \\
$\mathrm{H}, \mathrm{CF}_{3}(\mathbf{1} \mathbf{c})$ & $1.765(2)$ & $1.737(2)$ & $-1.6 \%$ & {$[17]$}
\end{tabular}




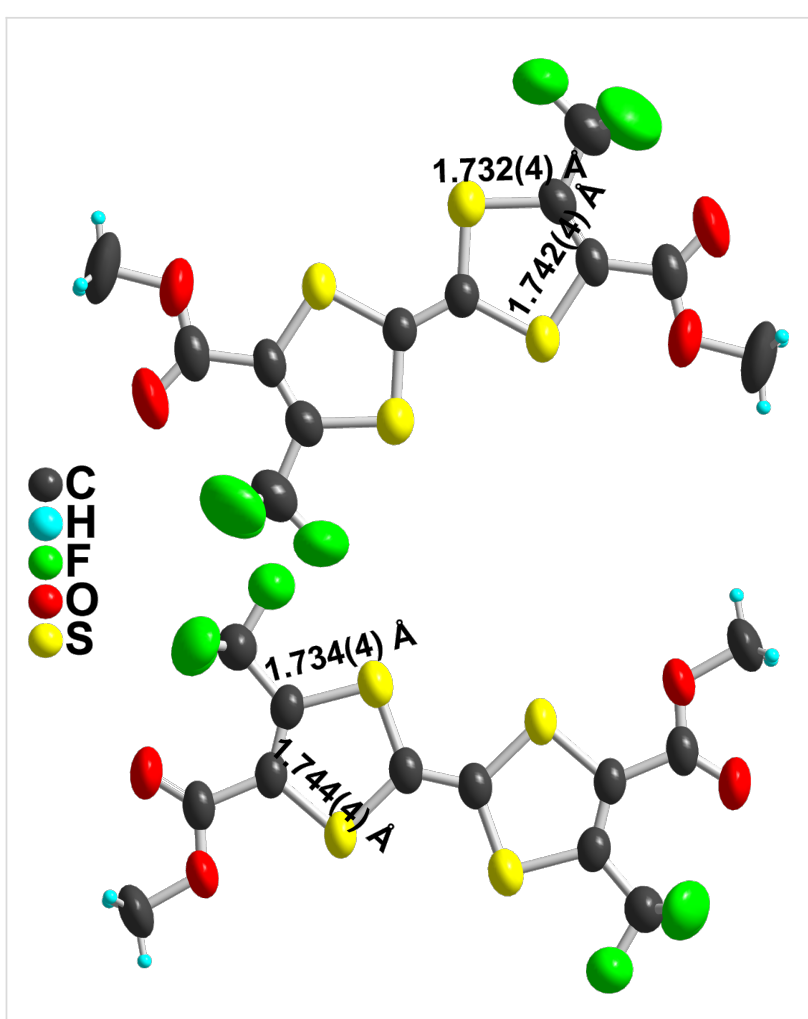

Figure 5: View of the two crystallographically independent $\mathbf{4 b c}$ molecules. Thermal ellipsoids are shown at the $50 \%$ probability level.

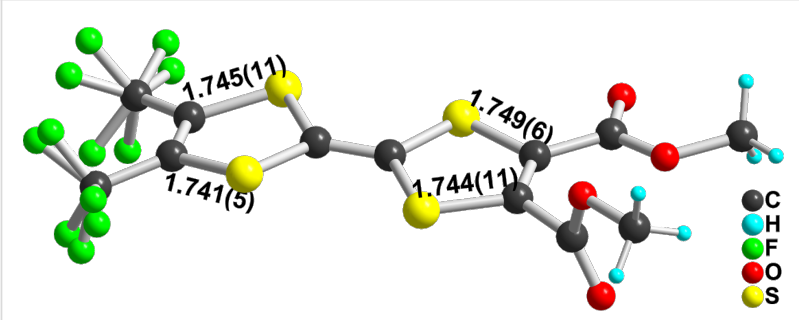

Figure 6: View of the 3bc molecule. Note the disordered $\mathrm{CF}_{3}$ groups as well as the $\mathrm{CO}_{2} \mathrm{Me}$ group orthogonal to the TTF plane.

above. Furthermore, the two ester groups are not coplanar, one of them lies flat with the TTF core while the other one is almost perpendicular.

\section{Charge-transfer complex and radical cation salt}

The relatively low oxidation potential of the mono(trifluoromethyl) derivative $1 \mathrm{c}\left(+0.21 \mathrm{~V}\right.$ vs $\left.\mathrm{Fc}^{+} / \mathrm{Fc}\right)$ prompted us to investigate the formation of cation radical salts upon chemical or electrochemical oxidation of 1c. Indeed, treatment of a solution of 1c with TCNQ afforded black, crystalline elongated plates which were analyzed to be a $2: 1$ complex, i.e., (1c) $)_{2}$ (TCNQ). Electrocrystallization experiments were conducted with $\mathbf{1 c}$ as well as $\mathbf{2 c c}$ with a variety of anions, be they linear such as $\mathrm{AuBr}_{2}{ }^{-}, \mathrm{I}_{3}{ }^{-}, \mathrm{ICl}_{2}{ }^{-}$, tetrahedral $\left(\mathrm{ReO}_{4}{ }^{-}, \mathrm{InBr}_{4}{ }^{-}\right)$or octahedral $\left(\mathrm{AsF}_{6}{ }^{-}\right)$. In most cases however, the electrochemically generated salts were extremely soluble, a consequence of the presence of the $\mathrm{CF}_{3}$ groups and there was no crystal growth on the anode. However, with $\mathbf{1 c}$ as electroactive donor molecule and $\left(n-\mathrm{Bu}_{4} \mathrm{~N}\right)\left(\mathrm{FeCl}_{4}\right)$ as electrolyte, layering of the $\mathrm{CH}_{2} \mathrm{Cl}_{2}$ solutions after electrolysis with pentane afforded crystals of a $1: 1$ phase formulated as $(\mathbf{1 c})\left(\mathrm{FeCl}_{4}\right)$.

(1c) $)_{2}$ (TCNQ) crystallizes in the monoclinic system, space group $P 2_{1} / c$. One TCNQ molecule located on an inversion center and the EDT-TTF-CF 3 molecule in general position in the unit cell generate molecular triads (1c)(TCNQ)(1c) which stack along the $b$ axis (Figure 7).

The degree of charge-transfer within this system can be anticipated to be close to zero from the comparison of the redox potentials of EDT-TTF- $\mathrm{CF}_{3}\left(E_{\mathrm{Ox}}{ }^{1 / 2}=0.21 \mathrm{~V} \mathrm{vs} \mathrm{Fc}^{+} / \mathrm{Fc}\right)$ and $\operatorname{TCNQ}\left(E_{\mathrm{red}}{ }^{1 / 2}=-0.23 \mathrm{~V}\right.$ vs Fc${ }^{+} / \mathrm{Fc}, 0.17 \mathrm{~V}$ vs SCE$)$ [43]. This is also confirmed from the intramolecular bond lengths (Table 5) within the central $\mathrm{C}_{2} \mathrm{~S}_{4}$ core of the donor molecule, close to those observed in neutral EDT-TTF- $\mathrm{CF}_{3}(2)$ itself. The geometry of TCNQ can also give another evaluation of the degree of charge transfer. Based on the large number of reported TCNQ salts, three different correlations between the charge of the molecule and the bond lengths have been reported [44-46]. Applying those three correlations to the TCNQ bond lengths in (1c) $)_{2}$ (TCNQ), averaged in $D_{2 h}$ symmetry, gives calculated charges of $-0.08,+0.11$ and -0.16 , confirming that we are here in presence of a neutral charge-transfer complex rather than a charge-transfer salt.

Note also that this donor-acceptor interaction leads to a strong planarization of the dithiole rings of $1 \mathbf{c}$ in (1c) $)_{2}$ (TCNQ) with folding angles along the $\mathrm{S} \cdots \mathrm{S}$ hinge of the two dithiole rings amounting now to $10.13(17)^{\circ}$ and $1.90(16)^{\circ}$ on the dithioethylene and $\mathrm{CF}_{3}$ sides, respectively. By comparison, in the neutral donor molecule 1c, the folding angles amount to $20.59(5)$ and $19.00(5)^{\circ}$ respectively [31]. Such $\pi-\pi$ interactions have been shown to derive from quadrupolar interactions between the $\pi$ systems of both donor and acceptor moieties [47], and their geometrical characteristics to favor the strongest electrostatic interactions between the most electron-rich and electron-poor regions of both partners. In that respect, it appears here that the TCNQ acceptor essentially overlaps with the dithiole ring bearing the dithioethylene substituent, a likely consequence of the electron-withdrawing effect of the $\mathrm{CF}_{3}$ group on the other dithiole ring (Figure 8).

In the $1: 1$ salt of EDT-TTF- $\mathrm{CF}_{3}(\mathbf{1 c})$ with $\mathrm{FeCl}_{4}{ }^{-}$, that is $\left(\mathbf{1 c}^{+\bullet}\right)\left(\mathrm{FeCl}_{4}^{-}\right)$, oxidation to the radical cation state strongly 

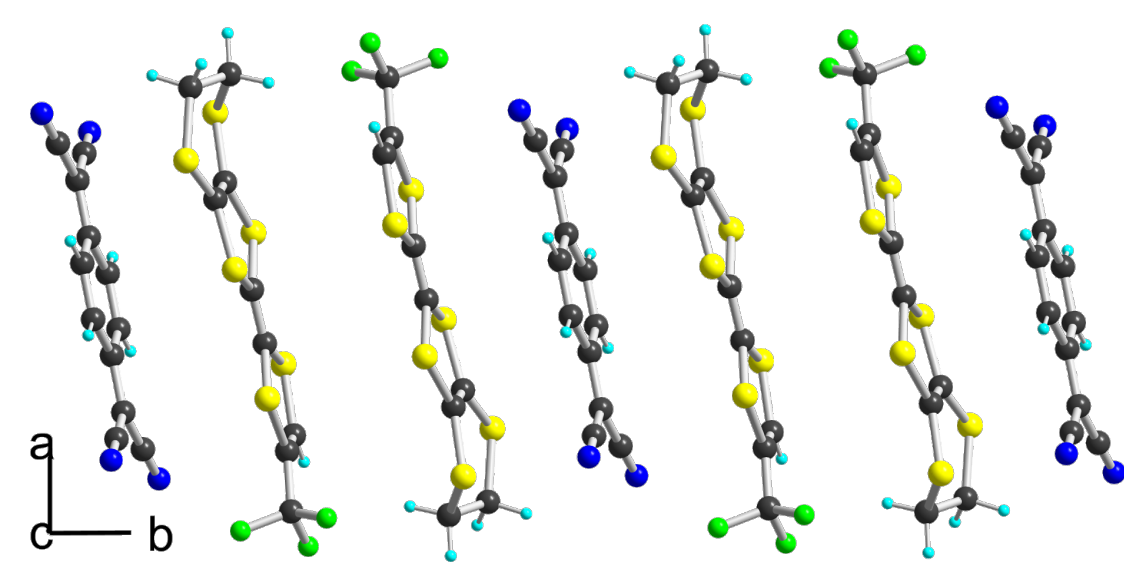

Figure 7: A view of the alternated stacks along the $b$ axis in (1c) $)_{2}(\mathrm{TCNQ})$.

Table 5: Structural characteristics of the $\mathrm{C}_{2} \mathrm{~S}_{4}$ central core in EDT-TTF-CF 3 (1c) derivatives. $\rho$ is the charge of $1 \mathrm{c}$ in the different combinations Bonds $a(C=C)$ and $b, b^{\prime}, c, c^{\prime}\left(C_{\text {central }}-\mathrm{S}\right)$ are identified in the scheme below.<smiles>FC(F)(F)C1=CSC(=C2SC3=C(SCCS3)S2)S1</smiles>

\begin{tabular}{llllllll}
\hline & $\rho$ & $a(\AA)$ & $b(\AA)$ & $b^{\prime}(\AA)$ & $c(\AA)$ & $c^{\prime}(\AA)$ & references \\
\hline $1 \mathbf{c}$ & 0 & $1.348(3)$ & $1.755(2)$ & $1.758(2)$ & $1.759(2)$ & $1.759(2)$ & {$[17]$} \\
$(1 \mathrm{c})_{2} \mathrm{TCNQ}$ & $\approx 0$ & $1.336(4)$ & $1.756(15)$ & $1.763(6)$ & $1.756(6)$ & $1.755(15)$ & this work \\
$(1 \mathrm{c})\left(\mathrm{FeCl}_{4}\right)$ & $\approx 1$ & $1.382(6)$ & $1.727(4)$ & $1.733(4)$ & $1.723(4)$ & $1.708(4)$ & this work
\end{tabular}

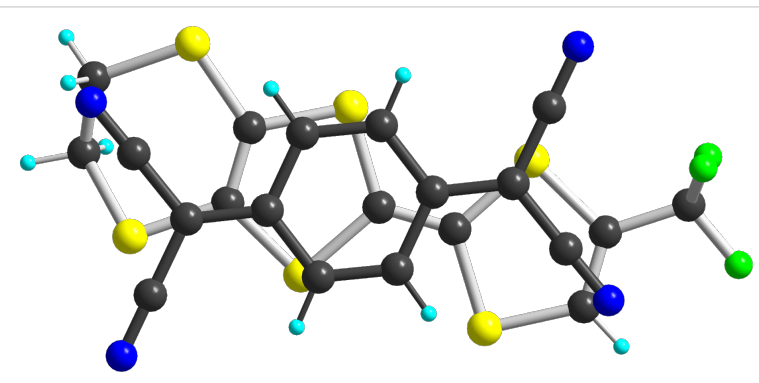

Figure 8: Detail of the overlap between donor and acceptor molecules in $(\mathbf{1 c})_{2}(\mathrm{TCNQ})$.

affects the central $\mathrm{C}_{2} \mathrm{~S}_{4}$ core of the donor (Table 4) with a lengthening of the $\mathrm{C}=\mathrm{C}$ central double bond $a$, and an associated shortening of the $\mathrm{C}_{\text {central }}-\mathrm{S}$ bonds $\left.b, b^{\prime}, c, c^{\prime}\right)$. Note that this effect is stronger on the $\left(c, c^{\prime}\right) \mathrm{C}_{\text {central }}-\mathrm{S}$ bonds of the most electron-rich dithiole ring bearing the dithioethylene substituent.

In the solid state (Figure 9), the molecules are separated from each other by the $\mathrm{FeCl}_{4}{ }^{-}$anions in the $(b, c)$ plane. Along the $a$ axis, they interact only laterally with long $\mathrm{S} \cdots \mathrm{S}$ intermolecular (>3.74 $\AA$ ) into uniform spin chains. This solid-state arrange- ment is reminiscent of that observed with the analogous nitrile substituted EDT-TTF, that is EDT-TTF-CN, in the similar 1:1 (EDT-TTF-CN $\left.{ }^{+}\right)\left(\mathrm{FeBr}_{4}{ }^{-}\right)$salt [9], demonstrating that the $\mathrm{CF}_{3}$ moiety does not play here a crucial role in the solid state organization. Note that both charge transfer complex $(2)_{2}$ (TCNQ) and cation radical salt $(2)\left(\mathrm{FeCl}_{4}\right)$ are expected to behave as insulators, because of zero charge transfer in the former and full charge-transfer in the latter. We were not able to determine the magnetic response of the $\mathrm{FeCl}_{4}{ }^{-}$salt as the crystals are polluted with the starting electrolyte, due to the precipitation technique used to recover these highly soluble salts.

\section{Conclusion}

Compared with other EWG such as $-\mathrm{CN}$ or $-\mathrm{CO}_{2} \mathrm{Me}$, the $\mathrm{CF}_{3}$ substituent plays on the TTF electroactive core a peculiar role. From an electrochemical point of view, comparison of the relative role of the $\mathrm{CN}, \mathrm{CO}_{2} \mathrm{Me}$ and $\mathrm{CF}_{3}$ EWG shows that, the electron-withdrawing nature of the $\mathrm{CF}_{3}$ moiety is intermediate between that of the $\mathrm{CN}$ and the $\mathrm{CO}_{2} \mathrm{Me}$ ones. On the other hand, the structural distortions introduced on the dithiole ring upon substitution with the $\mathrm{CN}$ and $\mathrm{CO}_{2} \mathrm{Me}(-\mathrm{M})$ EWG are not offset by the competing $\mathrm{CF}_{3}$ group, confirming its much weaker mesomeric effect on the conjugated dithiole core. Optical prop- 


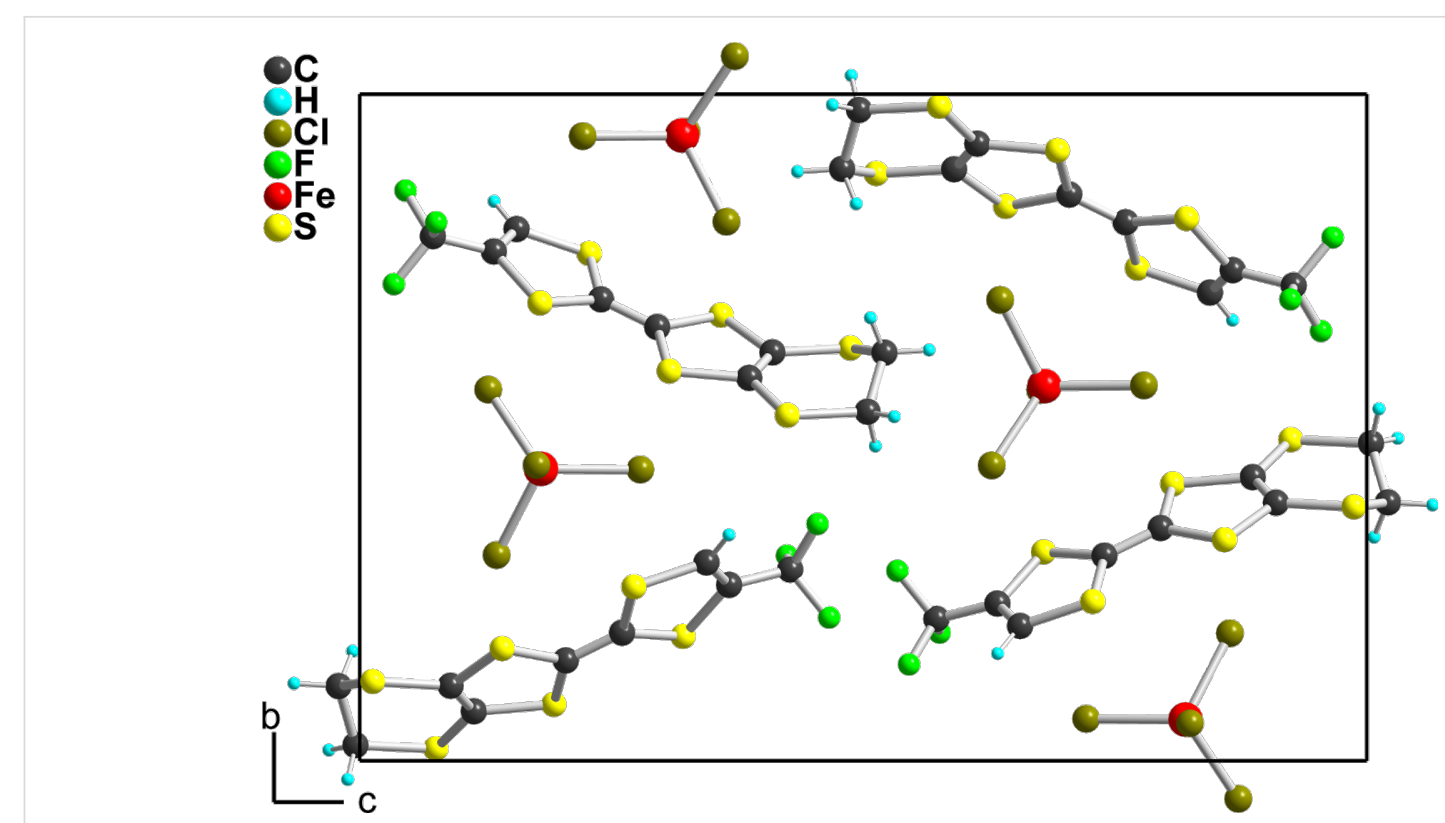

Figure 9: Projection view along the a axis of the unit cell of $\left(\mathbf{1 c}^{+\cdot}\right)\left(\mathrm{FeCl}_{4}{ }^{-}\right)$.

erties and theoretical calculations have shown that the HOMO-LUMO gap is not much modified in the $\mathrm{CF}_{3}$-substituted molecules, in sharp contrast with those TTF derivatives with $\mathrm{CN}$ or $\mathrm{CO}_{2} \mathrm{Me} \mathrm{EWG}$. In the latter indeed, the large stabilization of the LUMO localized on the EWG leads to a strongly decreased HOMO-LUMO gap associated with the well known dark color of these derivatives. Despite relatively high oxidation potentials, these donor molecules with $\mathrm{CF}_{3} \mathrm{EWG}$ can be involved in charge transfer complexes or cation radical salts, as reported here for the $\mathrm{CF}_{3}$-substituted EDT-TTF donor molecule, in its 2:1 neutral CT complex with TCNQ, $(\mathbf{1 c})_{2}$ (TCNQ) or its cation radical salt with $\mathrm{FeCl}_{4}^{-}$. The high solubility brought by the trifluoromethyl substituent strongly limits the isolation of such salts by crystallization.

\section{Experimental}

\section{General information}

Commercially available reagents were used without further purification. Solvents were distilled under Ar. THF and $\mathrm{Et}_{2} \mathrm{O}$ were dried over $\mathrm{KOH}$ before distillation from $\mathrm{Na}$ /benzophenone. $\mathrm{CH}_{3} \mathrm{CN}$ and $\mathrm{CH}_{2} \mathrm{Cl}_{2}$ were distilled over $\mathrm{P}_{2} \mathrm{O}_{5}$ and $\mathrm{MeOH}$ over $\mathrm{Mg} / \mathrm{I}_{2}$. Column chromatography was performed on silica gel. ${ }^{1} \mathrm{H},{ }^{13} \mathrm{C}$ and ${ }^{19} \mathrm{~F}$ NMR spectra were obtained on a Bruker Avance DRX500 spectrometer at $500.04 \mathrm{MHz}$ for ${ }^{1} \mathrm{H}$, 470.28 MHz for ${ }^{19} \mathrm{~F}$ and $125.75 \mathrm{MHz}$ for ${ }^{13} \mathrm{C}$. Chemical shifts were recorded in parts per million (ppm) downfield from tetramethylsilane (TMS). Coupling constants $(J)$ are reported in $\mathrm{Hz}$ and refer to apparent peak multiplications. The abbreviations $\mathrm{s}$ and q stand for singlet and quartet. Elemental analyses were performed at the Service de Microanalyses, Institut de Chimie des Substances Naturelles (ISCN), Gif/Yvette (France). MALDI-TOF MS spectra were obtained from a Bruker BiflexIIITM equipped with a $337 \mathrm{~nm}$ laser.

\section{Syntheses}

Preparation of EDT-TTF $\left(\mathrm{CONH}_{2}\right)\left(\mathrm{CF}_{3}\right)$ (7): EDT$\mathrm{TTF}\left(\mathrm{CO}_{2} \mathrm{Me}\right)\left(\mathrm{CF}_{3}\right)$ (2bc) [17] $(0.2 \mathrm{~g}, 0.47 \mathrm{mmol})$ was added to a $\mathrm{MeOH}$ solution $(20 \mathrm{~mL})$ saturated with gaseous $\mathrm{NH}_{3}$. The resulting suspension was stirred for $90 \mathrm{~min}$ and filtered. The solid was recrystallized from $\mathrm{CH}_{3} \mathrm{CN}$ to afford 7 as red-burgundy needles (120 mg, $0.3 \mathrm{mmol})$. Yield: 63\%; mp dec. $150-160{ }^{\circ} \mathrm{C} ;{ }^{1} \mathrm{H}$ NMR $\left(d_{6}\right.$-acetone) $\delta 3.44(\mathrm{~s}, 4 \mathrm{H})$, $7.48 \mathrm{ppm}(\mathrm{d}, 2 \mathrm{H}) ;{ }^{19} \mathrm{~F}$ NMR $\left(\mathrm{CDCl}_{3}\right) \delta-58.53$ (s) ppm. Anal. calcd for $\mathrm{C}_{10} \mathrm{H}_{6} \mathrm{~F}_{3} \mathrm{NOS}_{6}$ : C, 29.62; H, 1.49; N, 3.45; found: $\mathrm{C}$, 29.57; H, 1.34; N, 3.39; MS m/z: calcd, 404.87, found, 404.90 .

Preparation of EDT-TTF $(\mathrm{CN})\left(\mathrm{CF}_{3}\right)$ (2ac): A solution of EDT-TTF $\left(\mathrm{CONH}_{2}\right)\left(\mathrm{CF}_{3}\right)(7)(0.3 \mathrm{~g}, 0.74 \mathrm{mmol})$ and $\mathrm{POCl}_{3}$ $(0.2 \mathrm{~mL}, 2.15 \mathrm{mmol})$ in sulfolane $(4 \mathrm{~mL})$ is heated under stirring at $110{ }^{\circ} \mathrm{C}$ for $5 \mathrm{~h}$. After cooling, the solution is poured in $100 \mathrm{~mL}$ of iced water and filtered. The dried precipitate is purified twice by column chromatography on silica gel with dichloromethane elution. Crystals were obtained by diffusion of pentane into a concentrated dichloromethane solution $(0.17 \mathrm{~g}$, $0.044 \mathrm{mmol})$. Yield: $60 \%$; mp $176{ }^{\circ} \mathrm{C}\left(\mathrm{CH}_{2} \mathrm{Cl}_{2} /\right.$ hexane $)$; ${ }^{1} \mathrm{H} \mathrm{NMR}\left(\mathrm{CDCl}_{3}\right) \delta 3.32(\mathrm{~s}, 4 \mathrm{H}) \mathrm{ppm} ;{ }^{13} \mathrm{C} \mathrm{NMR}\left(\mathrm{CDCl}_{3}\right)$ $\delta 30.10(\mathrm{~s}), 104.58(\mathrm{~s}), 107.86\left(\mathrm{q}, J^{3} \mathrm{CF}=3.84 \mathrm{~Hz}\right), 108.47(\mathrm{~s})$, $113.97(\mathrm{~s}), 114.20(\mathrm{~s}), 118.81\left(\mathrm{q}, J^{1}{ }_{\mathrm{CF}}=274.47 \mathrm{~Hz}\right), 118.30(\mathrm{~s})$, $138.43\left(\mathrm{q}, J^{2} \mathrm{CF}=36.47 \mathrm{~Hz}\right) \mathrm{ppm} ;{ }^{19} \mathrm{~F} \mathrm{NMR}\left(\mathrm{CDCl}_{3}\right) \delta-59.20$ (s) ppm; Anal. calcd for $\mathrm{C}_{10} \mathrm{H}_{4} \mathrm{~F}_{3} \mathrm{NS}_{6}$ : C, 30.99; $\mathrm{H}, 1.04$; N, 
3.61; found: C, 30.82; H, 1.01; N, 3.49; MS m/z: calcd, 386.86, found, 386.69 .

Preparation of $o-\mathrm{TTF}\left(\mathrm{CO}_{2} \mathrm{Me}\right)_{2}\left(\mathrm{CF}_{3}\right)_{2}(3 \mathrm{bc})$ : A solution of bis(trifluoromethyl)-1,3-dithiole-2-thione (9cc) (2 g, $7 \mathrm{mmol}$ ) and bis(carbomethoxy)-1,3-dithiole-2-thione (10bb) (6 g, $24 \mathrm{mmol})$ in $\mathrm{P}(\mathrm{OMe})_{3}(15 \mathrm{~mL})$ is heated at $110^{\circ} \mathrm{C}$ for $16 \mathrm{~h}$. After evaporation of the solvent under vacuum, the crude residue is purified twice by chromatography on silica gel with pentane/dichloromethane elution (50:50). The red fraction was collected and crystallized from $\mathrm{CH}_{2} \mathrm{Cl}_{2} /$ hexane $(0.51 \mathrm{~g}$, $1.1 \mathrm{mmol}$ ). Yield: $15 \%$; mp $75^{\circ} \mathrm{C} ;{ }^{1} \mathrm{H} \mathrm{NMR}\left(\mathrm{CDCl}_{3}\right) \delta 3.86(\mathrm{~s}$, 6H) ppm; ${ }^{13} \mathrm{C} \mathrm{NMR}\left(\mathrm{CDCl}_{3}\right) \delta 54.04(\mathrm{~s}), 104.74(\mathrm{~s}), 114.74(\mathrm{~s})$, $119.21\left(\mathrm{q}, J^{1}{ }_{\mathrm{CF}}=276 \mathrm{~Hz}\right)(\mathrm{s}), 129.05\left(\mathrm{q}, J^{2}{ }_{\mathrm{CF}}=42 \mathrm{~Hz}\right), 132.41$ (s), 159.83 (s) ppm; ${ }^{19} \mathrm{~F} \mathrm{NMR}\left(\mathrm{CDCl}_{3}\right) \delta-56.25$ (s) ppm; Anal. calcd for $\mathrm{C}_{12} \mathrm{H}_{6} \mathrm{~F}_{6} \mathrm{O}_{4} \mathrm{~S}_{4}$ : C, 31.58; $\mathrm{H}, 1.33$; found: $\mathrm{C}, 31.79 ; \mathrm{H}$, 1.14; MS $m / z$ : calcd, 455.91; found, 455.6.

Preparation of (1c) $)_{2}$ (TCNQ): EDT-TTF-CH $(\mathbf{1 c})(20 \mathrm{mg}$, $\left.5.5 \times 10^{-5} \mathrm{~mol}\right)$ and TCNQ $\left(5.6 \mathrm{mg}, 2.75 \times 10^{-5} \mathrm{~mol}\right)$ were dissolved in hot $\mathrm{CH}_{3} \mathrm{CN}(2 \mathrm{~mL})$ and the mixture slowly cooled to room temperature. No crystal formation was observed at this stage. The solution is allowed to stand in a fridge for 15 days to produce thin needles which were filtered and recrystallized by slow evaporation in $\mathrm{CH}_{3} \mathrm{CN}$ to give the title compound as elongated black plates (20 mg, 78\%); Anal. calcd for $\mathrm{C}_{30} \mathrm{H}_{14} \mathrm{~F}_{6} \mathrm{~N}_{4} \mathrm{~S}_{12}$ : C, 38.78; H, 1.52; N, 6.03; found: C, 38.61; $\mathrm{H}$, $1.51 ; \mathrm{N}, 6.08 ;$ IR $v_{\mathrm{CN}}(\mathrm{KBr}): 2222 \mathrm{~cm}^{-1}$.

Preparation of (1c) $\left(\mathrm{FeCl}_{4}\right)$ : The electrocrystallization of $\mathbf{1 c}$ $(11 \mathrm{mg})$ in a $\mathrm{CH}_{2} \mathrm{Cl}_{2}$ solution $(15 \mathrm{~mL})$ of $\left(\mathrm{Et}_{4} \mathrm{~N}\right)\left(\mathrm{FeCl}_{4}\right)$ (208 mg) as electrolyte did not afford any crystals. Further layering of the solution recovered from the anodic compartment with pentane afforded dark crystals of a 1:1 phase formulated as $(\mathbf{1 c})\left(\mathrm{FeCl}_{4}\right)$, polluted with the yellow crystals of $\left(\mathrm{Et}_{4} \mathrm{~N}\right)\left(\mathrm{FeCl}_{4}\right)$.

\section{Crystallography}

Single crystals were mounted on the top of a thin glass fiber. Data were collected either on a Stoe-IPDS at room temperature or on a Nonius KappaCCD diffractometer at $150 \mathrm{~K}$, both equipped with graphite-monochromated Mo K $\alpha$ radiation

\begin{tabular}{|c|c|c|c|c|c|c|}
\hline compound & $2 a c$ & $2 b c$ & $3 b c$ & $4 b c$ & $(1 \mathrm{c})_{2} \mathrm{TCNQ}$ & $(1 \mathrm{c}) \mathrm{FeCl}_{4}$ \\
\hline formula & $\mathrm{C}_{10} \mathrm{H}_{4} \mathrm{~F}_{3} \mathrm{NS}_{6}$ & $\mathrm{C}_{11} \mathrm{H}_{7} \mathrm{~F}_{3} \mathrm{O}_{3} \mathrm{~S}_{6}$ & $\mathrm{C}_{12} \mathrm{H}_{6} \mathrm{~F}_{6} \mathrm{O}_{4} \mathrm{~S}_{4}$ & $\mathrm{C}_{12} \mathrm{H}_{6} \mathrm{~F}_{6} \mathrm{O}_{4} \mathrm{~S}_{4}$ & $\mathrm{C}_{15} \mathrm{H}_{7} \mathrm{~F}_{3} \mathrm{~N}_{2} \mathrm{~S}_{6}$ & $\mathrm{C}_{9} \mathrm{H}_{5} \mathrm{Cl}_{4} \mathrm{~F}_{3} \mathrm{FeS}_{6}$ \\
\hline fw & 387.50 & 420.53 & 456.41 & 456.41 & 464.59 & 560.14 \\
\hline cryst syst & monoclinic & triclinic & monoclinic & orthorhombic & monoclinic & orthorhombic \\
\hline space group & $P 2_{1}$ & $P-1$ & $P 2_{1} / a$ & Pbam & $P 2_{1} / c$ & $P 2{ }_{1}{ }_{1} 2_{1}$ \\
\hline$a / \AA$ & $5.0849(5)$ & $5.1515(12)$ & $7.4209(8)$ & $28.000(3)$ & $13.2146(15)$ & $5.9348(5)$ \\
\hline$b / \AA ̊$ & $10.9285(12)$ & $11.998(2)$ & $17.0659(17)$ & $8.7129(9)$ & $11.1448(8)$ & $14.4165(15)$ \\
\hline$c / \AA$ & $12.7619(13)$ & $12.974(3)$ & $13.5707(15)$ & $7.2091(7)$ & $13.1662(15)$ & $21.785(2)$ \\
\hline$\alpha / \operatorname{deg}$ & 90 & 103.96(3) & 90 & 90 & 90 & 90 \\
\hline$\beta / \operatorname{deg}$ & $97.741(12)$ & $90.02(3)$ & $97.834(13)$ & 90 & $106.997(13)$ & 90 \\
\hline y/deg & 90 & $90.45(3)$ & 90 & 90 & 90 & 90 \\
\hline$V I \AA^{3}$ & $702.72(13)$ & $778.2(3)$ & $1702.6(3)$ & $1758.8(3)$ & 1854.3(3) & 1863.9(3) \\
\hline Z & 2 & 2 & 4 & 4 & 4 & 4 \\
\hline$d_{\text {calc }} / \mathrm{Mg} \mathrm{m}^{-3}$ & 1.831 & 1.795 & 1.781 & 1.724 & 1.664 & 1.996 \\
\hline diffractometer & Stoe-IPDS & Stoe-IPDS & Stoe-IPDS & Stoe-IPDS & Stoe-IPDS & KappaCCD \\
\hline temp/K & $293(2)$ & 293(2) & $293(2)$ & 293(2) & 293(2) & $150(2)$ \\
\hline$\mu / \mathrm{mm}^{-1}$ & 0.991 & 0.910 & 0.636 & 0.616 & 0.768 & 2.072 \\
\hline$\theta$-range/deg & $2.45-25.75$ & $1.75-25.94$ & $1.85-25.85$ & $2.45-25.98$ & $2.44-25.83$ & $2.34-26.02$ \\
\hline measured refls & 6805 & 7498 & 12937 & 10664 & 13683 & 38263 \\
\hline indep. refls & 2682 & 2778 & 3263 & 1861 & 3518 & 3675 \\
\hline$R_{\text {int }}$ & 0.0334 & 0.126 & 0.0639 & 0.0815 & 0.065 & 0.109 \\
\hline $\mathrm{I}>2 \sigma(\mathrm{I})$ refls & 1986 & 989 & 2161 & 833 & 2190 & 2932 \\
\hline abs. corr. & multi-scan & none & gaussian & multi-scan & multi-scan & multi-scan \\
\hline$T_{\max }, T_{\min }$ & $0.786,0.851$ & - & $0.782,0.901$ & $0.937,0.927$ & $0.912,0.822$ & $0.769,0.733$ \\
\hline refined params & 199 & 199 & 289 & 151 & 236 & 228 \\
\hline$R(F), I>2 \sigma(I)$ & 0.0327 & 0.0442 & 0.0320 & 0.0342 & 0.0339 & 0.0410 \\
\hline$w R\left(F^{2}\right)$, all & 0.0765 & 0.0909 & 0.0783 & 0.0654 & 0.0814 & 0.0538 \\
\hline res. $\Delta \rho\left(e \AA^{-3}\right)$ & $+0.297,-0.357$ & $+0.29,-0.28$ & $0.211,-0.166$ & $+0.18,-0.16$ & $+0.32,-0.20$ & $+0.41,-0.42$ \\
\hline
\end{tabular}


$(\lambda=0.71073 \AA)$. Structures were solved by direct methods (SHELXS-97) and refined (SHELXL-97) [48] by full-matrix least-squares methods, as implemented in the WinGX software package [49]. Absorption corrections were applied. Hydrogen atoms were introduced at calculated positions (riding model), included in structure factor calculations, and not refined. Crystallographic data are summarized in Table 6 .

\section{Computational details}

DFT $[50,51]$ calculations were performed with the hybrid Becke-3 parameter exchange functional [52-54] and the Lee-Yang-Parr nonlocal correlation functional [55] (B3LYP) implemented in the Gaussian 03 (revision D.02) program suite [56], using the 6-31G(d) basis set and a quadratically convergent self-consistent field procedure with the default convergence criteria implemented in the program. The X-ray diffraction data of model compounds were used as a starting point for initial geometry optimization calculations. Final geometries are given in Supporting Information File 1. Representation of frontier orbitals included in Figure 2 were generated with Molekel 4.3 [57]. TD-DFT calculations were performed at the B3LYP/6-311G** level of theory, on the previously converged geometries.

\section{Supporting Information}

\section{Supporting Information File 1}

Optimized geometries of the model molecules TTF, $\mathrm{TTF}-\mathrm{CN}, \mathrm{TTF}-\mathrm{CF}_{3}$ and $\mathrm{TTF}-\mathrm{CO}_{2} \mathrm{Me}$ and results of the TD-DFT calculations.

[http://www.beilstein-journals.org/bjoc/content/ supplementary/1860-5397-11-73-S1.pdf]

\section{Supporting Information File 2}

$\mathrm{X}$-ray data for the reported structures. [http://www.beilstein-journals.org/bjoc/content/ supplementary/1860-5397-11-73-S2.cif]

\section{Acknowledgements}

Financial support from Ministry of Higher Education and Research (France) through a Ph.D. grant to O. J. is acknowledged. The authors thank GENCI (France) for allocation of computing time under project c2015085032.

\section{References}

1. Batail, P., Ed. Molecular Conductors. Chem. Rev. 2004, 104, 4887-5781.

2. Hartzler, H. D. J. Am. Chem. Soc. 1973, 95, 4379-4387. doi:10.1021/ja00794a039
3. Scott, B. A.; Kaufman, F. B.; Engler, E. M. J. Am. Chem. Soc. 1976, 98 , 4342-4344. doi:10.1021/ja00430a070

4. Yoneda, S.; Kawase, T.; Inabe, M.; Yoshida, Z. J. Org. Chem. 1978, 43, 595-598. doi:10.1021/jo00398a015

5. Jørgensen, M.; Bechgaard, K. Synthesis 1989, 207-208. doi:10.1055/s-1989-27200

6. Imakubo, T.; Sawa, H.; Kato, R. Synth. Met. 1995, 73, 117-122. doi:10.1016/0379-6779(95)03322-X

7. Fourmigué, M.; Batail, P. Chem. Rev. 2004, 104, 5379-5418. doi:10.1021/cr030645s

8. Metrangolo, P.; Resnati, G., Eds. Halogen Bonding: Fundamentals and Applications; Structure and Bonding, Vol. 126; Springer: Berlin, Germany, 2007. doi:10.1007/978-3-540-74330-9

9. Fourmigué, M. Curr. Opin. Solid State Mater. Sci. 2009, 13, 36-45. doi:10.1016/j.cossms.2009.05.001

10. Batsanov, A. S.; Bryce, M. R.; Heaton, J. N.; Moore, A. J.; Skabara, P. J.; Howard, J. A. K.; Orti, E.; Viruela, P. M.; Viruela, R. J. Mater. Chem. 1995, 5, 1689-1696. doi:10.1039/jm9950501689

11. Devic, T.; Bertran, J. N.; Domercq, B.; Canadell, E.; Avarvari, N.; Auban-Senzier, P.; Fourmigué, M. New J. Chem. 2001, 25, 1418-1424. doi:10.1039/b104640n

12. Cooke, G.; Powell, A. K.; Heath, S. L. Synthesis 1995, 1411-1414. doi:10.1055/s-1995-4124

13. Zhong, Z. J.; You, X.-Z.; Yu, K. Acta Crystallogr., Sect. C 1996, 52, 449-451. doi:10.1107/S0108270195009942

14. Terkia-Derdra, N.; Andreu, R.; Sallé, M.; Levillain, E.; Orduna, J.; Garin, J.; Orti, E.; Viruela, R.; Pou-Amerigo, R.; Sahraoui, B.; Gorgues, A.; Favard, J.-F.; Riou, A. Chem. - Eur. J. 2000, 6, 1199-1213. doi:10.1002/(SICl)1521-3765(20000403)6:7<1199::AID-CHEM1199>3. 3.CO;2-7

15. Heuzé, K.; Fourmigué, M.; Batail, P. J. Mater. Chem. 1999, 9 , 2373-2379. doi:10.1039/a902852h

16. Baudron, S. A.; Avarvari, N.; Canadell, E.; Auban-Senzier, P.; Batail, P. Chem. - Eur. J. 2004, 10, 4498-4511. doi:10.1002/chem.200400153

17. Baudron, S. A.; Avarvari, N.; Batail, P.; Coulon, C.; Clérac, R.; Canadell, E.; Auban-Senzier, P. J. Am. Chem. Soc. 2003, 125, 11583-11590. doi:10.1021/ja0356129

18. Moore, A. J.; Bryce, M. R.; Batsanov, A. S.; Heaton, J. N.; Lehmann, C. W.; Howard, J. A. K.; Robertson, N.; Underhill, A. E.; Perepichka, I. F. J. Mater. Chem. 1998, 8, 1541-1550. doi:10.1039/a802037j

19. Batsanov, A. S.; Bryce, M. R.; Cooke, G.; Heaton, J. N.; Howard, J. A. K. J. Chem. Soc., Chem. Commun. 1993, 1701-1702. doi:10.1039/c39930001701

20. Batsanov, A. S.; Bryce, M. R.; Cooke, G.; Dhindsa, A. S.; Heaton, J. N.; Howard, J. A. K.; Moore, A. J.; Petty, M. C. Chem. Mater. 1994, 6, 1419-1425. doi:10.1021/cm00044a046

21. Heuzé, K.; Fourmigué, M.; Batail, P.; Canadell, E.; Auban-Senzier, P. Chem. - Eur. J. 1999, 5, 2971-2976. doi:10.1002/(SICI)1521-3765(19991001)5:10<2971::AID-CHEM2971> 3.0.CO;2-S

22. Heuzé, K.; Mézière, C.; Fourmigué, M.; Batail, P.; Coulon, C.; Canadell, E.; Auban-Senzier, P.; Jérome, D. Chem. Mater. 2000, 12, 1898-1904. doi:10.1021/cm000143k

23. Heuzé, K.; Fourmigué, M.; Batail, P.; Coulon, C.; Clérac, R.; Canadell, E.; Auban-Senzier, P.; Ravy, S.; Jérome, D. Adv. Mater. 2003, 15, 1251-1253. doi:10.1002/adma.200305247 
24. Devic, T.; Evain, M.; Moëlo, Y.; Canadell, E.; Senzier, P.; Fourmigué, M.; Batail, P. J. Am. Chem. Soc. 2003, 125, 3295-3301. doi:10.1021/ja0290431

25. Nishijo, J.; Ogura, E.; Yamaura, J.; Miyazaki, A.; Enoki, T.; Takano, T.; Kuwatani, Y.; lyoda, M. Solid State Commun. 2000, 116, 661-664. doi:10.1016/S0038-1098(00)00406-3

26. Devic, T.; Domercq, B.; Auban-Senzier, P.; Molinié, P.; Fourmigué, M. Eur. J. Inorg. Chem. 2002, 2844-2849. doi:10.1002/1099-0682(200211)2002:11<2844::AID-EJIC2844>3.0.CO ;2-J

27. Domercq, B.; Devic, T.; Fourmigué, M.; Auban-Senzier, P.; Canadell, E. J. Mater. Chem. 2001, 11, 1570-1575. doi:10.1039/b100103p

28. Bryce, M. R.; Moore, A. J.; Batsanov, A. S.; Howard, J. A. K.; Petty, M. C.; Williams, G.; Rotello, V.; Cuello, A. J. Mater. Chem. 1999, 9, 2973-2978. doi:10.1039/a905364f

29. Dhindsa, A. S.; Baydal, J. P.; Bryce, M. R.; Petty, M. C.; Moore, A. J.; Lvov, Y. M. J. Chem. Soc., Chem. Commun. 1990, 970-972. doi:10.1039/c39900000970

30. Dsindsa, A. S.; Song, Y. P.; Baydal, J. P.; Bryce, M. R.; L'vov, Y. M.; Petty, M. C.; Yarwood, J. Chem. Mater. 1992, 4, 724-728. doi:10.1021/cm00021a042

31. Jeannin, O.; Fourmigué, M. Chem. - Eur. J. 2006, 12, 2994-3005. doi:10.1002/chem.200501078

32. Dautel, O. J.; Fourmigué, M.; Canadell, E. Chem. - Eur. J. 2001, 7, 2635-2643. doi:10.1002/1521-3765(20010618)7:12<2635::AID-CHEM26350>3.0.C $0 ; 2-7$

33. Dautel, O. J.; Fourmigué, M. J. Org. Chem. 2000, 65, 6479-6486. doi:10.1021/jo000518I

34. Garreau, B.; De Montauzon, D.; Cassoux, P.; Legros, J.-P.; Fabre, J.-M.; Saoud, K.; Chakroune, S. New J. Chem. 1995, 19, 161-171.

35. Fourmigué, M.; Krebs, F. C.; Larsen, J. Synthesis 1993, 509-512. doi:10.1055/s-1993-25894

36. Garín, J.; Orduna, J.; Savirón, M.; Bryce, M. R.; Moore, A. J.; Morisson, V. Tetrahedron 1996, 52, 11063-11074. doi:10.1016/0040-4020(96)00624-2

37. Papavassiliou, G. C.; Zambounis, J. S.; Mousdis, G. A.; Gionis, V.; Yiannopoulos, S. Y. Mol. Cryst. Liq. Cryst. 1988, 156, 269-276. doi:10.1080/10441859.1988.11009204

38. Schukat, G.; Richter, A. M.; Fanghänel, E. Sulfur Rep. 1987, 7, 155-231. doi:10.1080/01961778708082503

39. Values of $s_{m}$ were taken from O. Exner in Correlation Analysis in Chemistry, N. B. Chapman and J. Shorter Eds, Plenum Press, New York, 1978.

40. Carey, F. A.; Sundberg, R. J. Advanced Organic Chemistry, Part A: Structure and Mechanisms; Plenum Press: New York, NY, U.S.A., 1984. doi:10.1007/978-1-4757-1143-1

41. The following values were used: $\mathrm{MeO}_{2} \mathrm{C}:+0.35 ; \mathrm{F}_{3} \mathrm{C}:+0.46$; $\mathrm{NC}$ : $+0.62 ; \mathrm{S}\left(\mathrm{CH}_{2}\right)_{2} \mathrm{~S}:+0.28$.

42. Khodorkovsky, V.; Edzina, A.; Neilands, O. J. Mol. Electron. 1989, 5, 33-36.

43. Wheland, R. C.; Gilson, J. L. J. Am. Chem. Soc. 1976, 98, 3916-3925. doi:10.1021/ja00429a030

44. Flandrois, S.; Chasseau, D. Acta Crystallogr., Sect. B 1977, 33, 2744-2750. doi:10.1107/S0567740877009406

45. Kistenmacher, T. J.; Emge, T. J.; Bloch, A. N.; Cowan, D. O. Acta Crystallogr., Sect. B 1982, 38, 1193-1199. doi:10.1107/S0567740882005275
46. Umland, T. C.; Allie, S.; Kulhman, T.; Coppens, P. J. Phys. Chem. 1988, 92, 6456-6460. doi:10.1021/j100333a053

47. Hunter, C. A.; Saunders, J. K. M. J. Am. Chem. Soc. 1990, 112, 5525-5534. doi:10.1021/ja00170a016

48. SHELX97 - Programs for Crystal Structure Analysis, Release 97-2; G. M. Sheldrick, 1998.

49. Farrugia, L. J. J. Appl. Crystallogr. 1999, 32, 837. doi:10.1107/S0021889899006020

50. Hohenberg, P.; Kohn, W. Phys. Rev. B 1964, 136, 864-871. doi:10.1103/PhysRev.136.B864

51. Parr, R. G.; Yang, W. Density-Functional Theory of Atoms and Molecules; Oxford University Press: Oxford, United Kingdom, 1989.

52. Becke, A. D. Phys. Rev. A 1988, 38, 3098-3100. doi:10.1103/PhysRevA.38.3098

53. Becke, A. D. J. Chem. Phys. 1993, 98, 1372-1377. doi:10.1063/1.464304

54. Becke, A. D. J. Chem. Phys. 1993, 98, 5648-5652. doi:10.1063/1.464913

55. Lee, C.; Yang, W.; Parr, R. G. Phys. Rev. B 1988, 37, 785-789. doi:10.1103/PhysRevB.37.785

56. Gaussian 03, Revision D.02; Gaussian, Inc.: Wallingford, CT, 2004.

57. MOLEKEL, 4.3; Swiss Center for Scientific Computing: Manno, Switzerland, 2000.

\section{License and Terms}

This is an Open Access article under the terms of the Creative Commons Attribution License (http://creativecommons.org/licenses/by/2.0), which permits unrestricted use, distribution, and reproduction in any medium, provided the original work is properly cited.

The license is subject to the Beilstein Journal of Organic Chemistry terms and conditions:

(http://www.beilstein-journals.org/bjoc)

The definitive version of this article is the electronic one which can be found at: $\underline{\text { doi: } 10.3762 / \text { bjoc } 11.73}$ 